\title{
Place, Placelessness and David Malouf's Meditation on the Dual Meaning of Possession: Is Haunting or Being Haunted Only about Expiation of Colonial Sins?
}

Christine Vandamme

\section{(2) OpenEdition}

\section{Journals}

Electronic version

URL: https://journals.openedition.org/ces/2418

DOI: $10.4000 /$ ces. 2418

ISSN: 2534-6695

Publisher

SEPC (Société d'études des pays du Commonwealth)

Electronic reference

Christine Vandamme, "Place, Placelessness and David Malouf's Meditation on the Dual Meaning of Possession: Is Haunting or Being Haunted Only about Expiation of Colonial Sins?", Commonwealth Essays and Studies [Online], 42.2 | 2020, Online since 30 September 2020, connection on 19 January 2022. URL: http://journals.openedition.org/ces/2418; DOI: https://doi.org/10.4000/ces.2418

This text was automatically generated on 19 January 2022

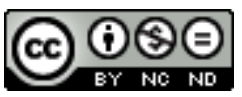

Commonwealth Essays and Studies is licensed under a Licence Creative Commons Attribution - Pas d'Utilisation Commerciale - Pas de Modification 4.0 International. 


\title{
Place, Placelessness and David Malouf's Meditation on the Dual Meaning of Possession: Is Haunting or Being Haunted Only about Expiation of Colonial Sins?
}

\author{
Christine Vandamme
}

David Malouf's "Blacksoil Country," like most stories in the Dream Stuff collection it belongs to, is an eerie and spectral short story which shares with the other stories a "dreamy" and even slightly nightmarish quality but in a very singular mode - what Derrida would call a hauntological mode. The related issues of possession, being possessed and haunted are omnipresent. Playing with absence and presence is taking up a recurrent feature in Australian literature and iconography, namely the lost child motif, it offers a reflection and a meditation on the issues of place and colonial appropriation. In other words, the notions of possession, dispossession and haunting recontextualise and reconfigure the question of belonging in a place which the settlers first designated as a terra nullius, a non-place or an unplaceable place. The short story thus illustrates what happens when the settlers themselves struggle with the very definition of place. It offers a reflection on the pre-established idea of the necessity of a collective Law or symbolic and social order to both define place and decide once and for all who is to be considered the rightful owner of a place, who is in his or her rightful place and ultimately who is rendered placeless and even unplaceable.

2 The tale is deeply ironical as one of its main protagonists, Mr McGivern, strives to impose on the Indigenes a system of ownership the rules of which he does not respect himself. He is only the tenant of a "run" owned by a certain McIvor and has thus no entitlement to the property he is supposed to control and secure against any resistance or encroachment on the part of the Aborigines living on the precincts of Mr McIvor's property. 
3 This is a story dealing with the early days of settlement but also, and more importantly still, a text which tackles the issue of dispossession, violence - both physical and symbolic - and the issue of haunting. But the spectres, and more particularly the spectral voice haunting the tale, are not just a way of atoning for the brutality of colonial times. They also have an ontological dimension pointing to an alternative future. The tale is a strong plea for the non-Indigenous Australians to reconnect not only with their past but also with the land, as well as its first inhabitants and their descendants, in emulating another way of relating to the place and accepting being possessed by it rather than appropriating it. It exposes the hollowness and illegitimacy of a social system in which a place is a purely abstract and symbolic construct devoid of any real value and use outside the settlers' framework and authority.

\section{Place, Placelessness and Restlessness: the Settlers' own Contradictions}

4 The short story reflects on the process of settling a place. And paradoxically, the central character, Mr McGivern, seems unable to settle anywhere because he refuses the very idea of authority and the symbolic and social order. His restlessness and inability to hold on to a place is linked to his subservient status which he cannot accept. As his own son remarks, Mr McGivern is restless, rendered placeless each time he decides to contest the authority he is supposed to "knuckle under": "There had been other places, a good many of them, where it didn't work. [...] I never once heard him put it down to anything he had done himself, to the trouble he had knuckling under or settling. It was always someone else was to blame" (Malouf 2001, 118-19). The father decides to pack and move elsewhere every time his employer is not fully satisfied with his work. On top of such intrinsic inability of the main character to settle anywhere, there is also the suggestion that the land itself resists settlement.

The very first paragraph of the tale points to the impossibility of controlling, delimiting or even inscribing any kind of property in the Australian bush, designated here as the eponymous "blacksoil country":

This is blacksoil country. Open, empty, crowded with ghosts, figures hidden away in the folds of it who are there, who are here, even if they are not visible and no one knows it but a few who look up suddenly into a blaze of sunlight and feel the hair crawl on their neck and know they are not the only ones. That they are being watched or tracked. They'll go on then with a sense for a moment that their body, as it goes, leaves no dent in the air. (Malouf 2001, 116)

Settling a place suggests fencing it off, drawing its confines, and yet the place is "open" and resists inscription: nobody seems to be able to "leav[e any] dent," whether in the air or on the ground, which defeats a colonial logic based on blind appropriation and conquest. The two-dimensional nature of claiming a piece of land on a map is here challenged by the suggestion of a three-dimensional reality: that of the Aborigines who hide in the "folds" of the land, and haunt it with their "ghostly" presence, but also that of the past, suggesting the settlers have deliberately omitted the past and the history of the place, the "archaeology of place" so to speak. Blacksoil country, just like Australia, resists mapping and settlement and the narrative voice underlines its paradoxes right away. It is "empty" but "crowded with ghosts"; it is both supposedly a terra nullius and haunted by numerous disembodied figures who turn out to be very real indeed as they are hiding from the white man and resisting being placed on either side of any fictive 
dividing line: they are both here and there because of their nomadic lifestyle and because they have always lived in Blacksoil country, contrary to the newcomers.

In the second sentence of the short story the narrative voice thus offers two contradictory visions: that of the settlers who have blindly decided they will settle the place and chase any Aborigine from the precincts of their newly acquired piece of land and for whom the place is or will be empty, and the few settlers who are perceptive enough to sense that the Aborigines are actually everywhere, that the country is "crowded with ghosts," or more precisely with tangible and visible figures who will not and cannot accept to be placed on any settler's map. From a colonial perspective based on binary oppositions such as inside/outside, refusing one's place is seen as trespassing, a form of provocation in itself.

7 So in this first paragraph spectrality is perceptible not simply because of the intermittent presence/absence of the Aborigines on their ancestral lands, but it is also created, and more surreptitiously still, by the divided nature of the narrative voice itself which seems to endorse a narrow colonial point of view when asserting the place is "empty" and then to express a contradictory point of view in noting the place is not actually empty but ghostly ("crowded with ghosts"). The reader is thus faced with two self-defeating visions, which are all the more unaccountable at this stage as the identity of the character-narrator has not been revealed yet. In the second paragraph the reader learns that the story is actually a first-person narrative told by a young boy, Jordan, and the end of the short story reveals that the boy was actually murdered because of his father's intolerance and killing of an Indigenous man. In the first sentence of the story, the as yet unidentified narrator Jordan thus keeps shifting from his father's and his community's prevailing vision, which is that the place is a terra nullius, an empty place, to his own vision which sees the place as "crowded" by its ancestral inhabitants. The doubling of both vision and voice creates a form of spectrality, to which the reader can decide to grant or refuse any credence. Malouf's cunning craftsmanship also lies in the delayed revelation of two essential elements: the identity of the narrator and the fact that Jordan McGivern, the eldest son of settler McGivern, is already dead, even though he addresses the reader as if he were still alive: "Jordan my name is. Jordan McGivern. I am twelve years old. I can show you this country. I been in it long enough" (Malouf 2001, 116). Such deferral of the origin of voice creates some unease and reinforces a sense of pervasive unreality and ghostliness.

Jordan's father is a particularly stubborn and narrow-minded man and Jordan is the only one in the family, except for his younger brother Jamie, to really establish a connection with the land and the Aborigines as a form of mutual recognition and acknowledgement, or at the very least mutual respect or tolerance of each other's presence. Contrary to his father, who seems to be so self-engrossed he fails to ever fully relate to the new place he has been sent to, the son immediately feels a form of unaccountable mystical bond with Blacksoil country:

This is my sort of country, I thought, the minute I first laid eyes on it. And the more I explored out into it the more I felt it was made for me and just set there, waiting. (Malouf 2001, 121)

[...] I'd wander off alone and pass right close to the [Aborigenes] and all they'd do, whatever they were engaged in, was look. They never offered any word of threat. They'd just look. (124) 

one day when he sees a group approaching. The man had been walking in his direction together with a few other natives so as to offer him a lamb in the hope of conciliation. The father wrongly interprets the move as a challenge to his authority and the legitimacy of his claim on the land. When he shouts for them to stop and they refuse to obey him, he fires and shoots dead the one in front. Unexpectedly his son Jordan, who witnesses the murder, then decides to take his father's side, as a form of loyalty to him.

The apparent opposition between father and son, between settling a place as a brutal and bloody type of appropriation on the one hand, and exploration and communion with the land as a form of humble and respectful approach to the place and its inhabitants on the other, is thus blurred and made problematic: the son's prompt allegiance to his father's adamant and ruthless imposition of what he considers his property rights is wholly unexpected, and the reader feels that some crucial piece of information has been withheld from them. The fact is that Jordan takes up the idea of ghostliness and the necessity to hide for anyone considered an intruder because as a "ghost," he is now in need of protection and must hide:

[...] now I kept a good eye open when [Jamie and I] were out together. The whole country had a new light over it. I had to look at it in a new way. What I saw in it was hiding-places. Places where they were hidden in it, the blacks. Places too where ghosts might be, also hidden. (Malouf 2001, 128)

He places himself and "the blacks" on the same level, as people obliged to turn into ghosts and to keep hiding in order to survive. But in the next two paragraphs he suddenly stops fully belonging to himself when he announces that the story he has been telling up till then was his whereas the one he is now going to tell is his father's. He even starts speaking of himself in the third person: "It is the story of a twelve-yearold boy treacherously struck down in the bush by unknown hands [...]" (128) To that extent we can effectively speak of a spectral narrative voice in Derridean terms "neither present nor absent, neither dead nor alive". ${ }^{1}$ Jordan's narrative voice is both and at the same time the voice of Jordan when he was still alive, the voice of Jordan when he was already dead, but also the ventriloquised voice of his father and his community when he starts speaking for them to explain their own understanding of the situation. The endless deferral of the origin for the narrative voice and main focaliser is made even more complex as it is unstable. Malouf sometimes uses McGivern junior to voice his own convictions about what type of relation to the land and the Indigenous people should have been adopted and at other times to voice a sense of irrepressible allegiance to the settlers' interests.

11 What is bewildering is the lack of any clear distanciation from the father's own views once the first act of violence, both symbolic and very concrete, is committed. The murder of the Aborigine for the sole reason that he was trespassing on "private" grounds turns into a blind spot for the son. At this stage in the short story the son seems to ventriloquise the father's own views as if he were possessed and deprived of his own voice and point of view. But this does not necessarily disqualify Malouf's writing or discredit his political positions for that matter, as will be demonstrated in the last part of the essay.

The central difficulty and uneasy question of where to place the origin of the narrative voice and focalisation starts with the first paragraphs of the tale. The first-person narrative dissociates the father's and the son's points of view at times and then, almost 
imperceptibly, seems to conflate them. When the narrator first identifies himself as Jordan, there is a striking switch from the first-person singular pronoun to the firstperson plural pronoun in the next paragraph. It gives the reader the false impression that father and son share a common and converging point of view:

Jordan my name is. Jordan MacGivern. I am 12 years old. I can show you this country. I been in it long enough.

When we first come up here, $\mathrm{Pa}$ and Ma and Jamie and me, we were the first ones on this bit of land [...].

When we come it was to settle. To manage and work a run of a thousand acres, unfenced and not marked out save on a map that wouldn't have covered more than a square handkerchief of it and could show nothing of what it was. How black the soil, how coarse and green the grass and stunted the scrub and how easy a mob can get lost in it. Or how the heat lies over it like a throbbing cloud all summer, and how the blacks are hidden away in it, ghosts that in those days were still visible and could stop you in your tracks. (Malouf 2001, 116-17)

The colonial vision of an almost incongruous two-dimensional map, the "square handkerchief" approach, is contradicted by the young character-narrator when Jordan insists the map could show nothing of what the area was really like. The map is misleading in suggesting the place was devoid of any human presence, by making the "hidden" natives invisible. In a way Jordan is systematically deconstructing the colonial appropriation of land in presenting side-by-side his father's vision and his own. The son's vision is much more vibrant and full of life. The anaphoric "how" tries to provide what Derrida would call a "supplement," what is always missing from any written sign, whether map or proper name such as "Blacksoil Country."

Such a passage illustrates a recurrent process throughout the short story, namely a dizzying plunge into the ever receding or morphing source of speech utterances. The disembodied narrative voice splits into two sources, passing from one to the other or even fusing them: Jordan expressing his own views, Jordan endorsing his father's worldview. The recurring spectrality of the story is the direct consequence of the presence/absence of a clearly identifiable character or speaker behind any utterance. But "Blacksoil Country" goes even further in its enterprise of uncanny destabilisation by questioning the very idea of authority, and of colonial authority for that matter.

The father's restlessness and resistance to authority further complexify any attempt to associate the ideas expressed with a specific voice. At one point Jordan says, in speaking of his father's failed attempts to settle down: "There had been other places, a good many of them, where it didn't work. He had no luck, Pa. After a time there was always some trouble. There was something in the work he was asked to do or the way the feller asked it, got his goat, and irked or offended him" (Malouf 2001, 118). In this first instance Jordan adopts his father's version, and accepts the idea that they have been moving from one place to the next because of bad luck. But he soon begins to see through his father's words and once again this creates a form of dissociation, estrangement and even spectrality. The shift from young and naïve Jordan's point of view to his older and more critical perspective is imperceptible and thus defeats any attempt at placing the "origin" of the narrative voice. The embodied narrator Jordan has become a ghost, hovering intermittently between gullible Jordan and his detached alter ego. The reader is given one version, and then another which invalidates the first one. As a result, the first version is progressively emptied of its validity and presented as a mere figment of the father's imagination. Such a systematic hollowing out of any character's beliefs and assertions as possibly no more grounded in facts and reality 
than any passing fancy - or passing spectre for that matter - is typical of the deconstructive mode of the story. It uses narrative voice to alert the reader to the inherently hauntological nature of both language and the symbolic order: the reality, presence and validity of any referent behind words or social regulations is only made possible as long as you accept to believe in them. Such a spectrality of the narrative voice is a recurring feature in Australian stories, many of which are written in a Gothic vein.

In Malouf's "Blacksoil Country," the proliferation of voices and points of view, as well as the challenge to both the employer's and the father's authority, goes hand in hand with the Gothic mode of the story, as defiance of authority is one of the Gothic's prototypical traits. In his book Peripheral Fear, Gerry Turcotte cogently notes that the Gothic vein typical of Australian literature shares with such a mode a taste for what Ruskin called "impatience of undue control, and that general tendency to set the individual reason against authority" (Turcotte 2009, 20). "Impatience of undue control" is what characterises the father. But what is even more striking and ironical is that once Jordan starts seeing through his father, he begins seeing connections between his father's reluctance to be told what to do and the Aborigines' own resentment against such imposition of another man's will. When the father cries out to his wife that the reason they cannot settle down is that he does not want to be treated like a "nigger," she could easily retort there is no reason why he himself should refuse the authority he wants to impose on others (Malouf 2001, 118-19). Jordan presents his father as an eternally dissatisfied figure who does not realise he would like every Aborigine to stay in his place, namely not interfere with him on what he wrongly considers his property, when he himself cannot accept the authority of his employer and the actual owner of the place. His inability to "knuckle under" (119) is echoed by the refusal of the Aborigines to regard the land as belonging to anyone in particular.

McGivern does not seem to realise that by killing on the run an Aborigine he is in charge of, he is precisely imposing his own hubristic and wilful force and authority onto the Aboriginal community, that he is trespassing on their own laws and symbolic order, thus endangering his own family's safety. The father won't admit either that the man he killed had come with peaceful intentions to give him an offering. He refuses to listen to his neighbour Mick Jolley who suggests he should pay the Aborigines a form of compensation to make peace now that he has killed one of them. He even stubbornly denies Indigenous people could have their own rules, as if being nomadic was incompatible with any social organisation:

He did not know that black was a messenger who had the right to pass through all territories without harm. [...] That there might be rules and laws hidden away in what was just makeshift savagery, hand-to-mouth getting from one day to the next and one place to another a little further on over the horizon - that would have seemed ridiculous to him. [...]. He had put us outside the rules, which all along, though he didn't see it that way had been their rules. (Malouf 2001, 127)

When Jordan is killed by the Aborigines as retaliation, the father does not reconsider his whole colonial outlook. He feels he has been vindicated in his first act of physical violence, not realising the violence was first symbolic, in appropriating a land and refusing free access to such a place to a nomadic people who consider the land as belonging to the community and not to anyone in particular. As a result of the murder, he ironically becomes a heroic figure among settlers, even though he used to be unpopular before. Such an apparently disillusioned conclusion to the story is 
misleading though, as the spectrality of the tale never fully disappears and the choice of a child narrator and victim enables Malouf to retain a form of innocence, and also to point to another form of relation to the land that the settlers, and their descendants more particularly, might still adopt. Jordan McGivern's point of view works on several levels: it suggests the possibility of a real communion with the land and it also deconstructs the very idea of possession as exclusive ownership. Possession in "Blacksoil Country" is all about humbleness and being possessed.

\section{Retrieving an Authentic Sense of Place: Possession as Communion and Immersion}

One of the twists in the short story is the peculiar status of a spectral presence, that of a dead child whose voice seems to speak from the underworld and to celebrate the blissful experience of communion with nature before the Fall so to speak. The story is all the more intriguing as it belongs to a long tradition of the lost child motif but as will be demonstrated, the prototypical child vanishing trope is given a wholly different ideological and political weight. When Jordan is killed by the Aborigines hiding in the folds of Blacksoil country, his body cannot be found for days and McGivern's neighbours organise search parties to look for him. Peter Pierce has devoted a study to this typically Australian anxiety, the disappearance and loss of children in the bush. He interprets it as revealing anxieties about the future and the intimation that Australia might never accept Western settlement:

But the deaths of young Australians, of children, are terrible, and are a more than personal or family matter. Their loss plays more heavily on the fears of Australians than adult catastrophes in the bush. Perhaps the travails and sometimes the deaths of children are emblematic either of the forfeiting of part of the national future, or of an anxiety that Australia will never truly welcome European settlement. (1999, 6; emphasis added)

19 A more recent volume by Elspeth Tilley goes further in identifying the lost child motif as only one subcategory of a more inclusive trope, that of the "lost-in-the-bush" figure. In her book White Vanishing. Rethinking Australia's Lost-in-the-Bush Myth, she examines what she calls the "white-vanishing trope - recurrent stories about white Australians who become lost or disappear into the landscape - as an enduring and powerful myth in white Australian settler culture" $(2012,1)$. In other words, she tries to account for the recurrence of the trope and explains what it reveals, culturally and ideologically. She sees in the "lost-in-the-bush" motif a narrative paradigm similar to Todorov's "equilibrium - disequilibrium - equilibrium narrative trajectory" (9). In the phase of disequilibrium, the white character leaves his or her familiar environment behind and experiences a form of estrangement:

[...] the character crosses a threshold that marks in some way departure from the known place; and s/he either goes beyond the boundaries of what the narrative can "know" or is immersed in an experience of strangeness, chaos, and disorientation in a space in which spatial and temporal conventions are disrupted. [...]

often the restoration of equilibrium involves making a claim or statement for white Australian mateship; invariably, it involves making a claim or statement about white relationships with land and establishing at least some portion of that land as an unequivocal white 'homescape'. (9-10) 
alouf's "Blacksoil Country," there are quite a few significant elements which do not fit or even contradict such a paradigmatic storyline. The one to cross the threshold which will bring disaster in its wake is not a white settler but the Aborigine, even if from a narrative and ethical point of view, Jordan consistently reminds the reader that the first transgression was really the father's imposition of his right of property onto the occupants of the place. At the end of the story all the settler community sticks together, thus re-enacting the original mateship myth, but it is at the expense of the son and it does not end with a claim on "at least some portion of that land as an unequivocal white "homescape'," as Tilley puts it. It is much more ambiguous than that but perhaps even more insidious. Jordan claims the land as his, insofar as his dead body, when reduced to grains, will blend with the "many black" grains countless Aborigines must have left before in dissolving into the landscape after their death. Poetically and aesthetically, it is a seductive metaphor as it seems to suggest a harmonious blending of black and white people, but politically it is not neutral:

The blacks in every direction are hunted and go to ground. They too have lost their protection - what little they had of it. And me all that while lying quiet in the heart of the country, slowly sinking into the ancientness of it, making it mine, grain by grain blending my white grains with its many black ones. (Malouf 2013, 129)

In such a passage Germaine Greer's unease about some form of whitewashing in Malouf's writings is not easily dismissed $(1993,11)$. The passage also evokes what Margery Fee calls a "literary land claim," which is commonly found in Romantic nationalist literature and tends to present the vanishing of Indigenous people as a wellknown law of nature $(2015,2)$. If anything, the idea that "blacks are hunted and go to ground" could be understood as a euphemism for their extermination or dispersal by the white man. Putting the death of the white settler's child on the same level as the possible murder of Indigenous people at the hands of the settlers is at best rather awkward.

21 The lost child motif in "Blacksoil Country" is thus ambivalent on account of the temptation to present white and black deaths as equivalent. And the sacrifice of the child is sufficiently strong emotionally to offer solid ground for imagined communities to capitalise on. With this original sacrifice the national epic can then unfold and build local or even national mythologies but in this particular case, there is no sense of a clean slate to start with. McGivern is no Abraham sacrificing his son Isaac, and the providential slate will be forever soiled by the blood of unnecessary victims on both sides. Such blood, like some invisible ink, keeps haunting national master narratives. Far from being positively connoted, the "homescape" of the settlers has become a place of massacres, violence and bloodshed, with the settlers' retaliation after Jordan's death.

And yet Malouf also suggests in his own poetic style that the only way forward is to accept one's past, look it in the eye so to speak and write about it instead of being eternally haunted by it. Through the figure of Jordan, at least when he was still alive, Malouf seems to grant all people living on the Australian soil the right to start developing their own way of relating to the land and to each other in as peaceful and understanding a manner as possible (this aspect will be further explored in the last part of the present essay).

Another significant divergence from the conventional narrative pattern is that Jordan, the child figure, does not experience any sense of "strangeness, chaos and disorientation in a space in which spatial and temporal conventions are disrupted"

Commonwealth Essays and Studies, 42.2 | 2020 
(Tilley 2012, 9) once he goes beyond the precincts of his father's property and starts wandering in the bush. He feels on the contrary a sense of profound connection: "This is my sort of country, I thought, the minute I first laid eyes on it. And the more I explored out into it the more I felt it was made for me and just set there, waiting" (Malouf 2001, 121-22). There is no idea of a horizontal movement or a threshold the child might be crossing, but rather that of a vertical move, of immersion: "[The place] was more than it looked. [...] There were things in it you had to get up close to, if you were to see what they really were - down on your knees, then sprawled out flat with your chest and your kneecaps touching it, feeling its grit" (122). Jordan longs so much for the embrace of the place that he starts going out at night to get a chance to feel enveloped by the sounds and the caress of the breeze.

The personification of the place and the gentle touch of its hands together with the recurrent use of synesthesia suggest an epiphanic moment of communion: "After a bit I would get up nights, let myself out and lie in some place out there under the stars. Letting the sounds rise up all around me in the heat, and letting a breeze touch me, if there was one, so I felt the touch of it on my bare skin like hands" (Malouf 2001, 122). Such a beautiful passage about the child's ability to connect with the land with all his body is representative of Malouf's style and approach to life. Like William Blake, he feels that childhood is a blessed period in life when all the doors of perception are wide open, ${ }^{3}$ and not yet partly or fully locked by the ideas, principles and representations one has been inculcated with. Here Jordan's every sense is on the alert and the images convey a feeling of incorporation into the landscape which is viewed positively as a form of fusion and communion, not an intimation of extinction or vanishing. Like the wild child in An Imaginary Life (1978), or Gemmy in Remembering Babylon (1993), Jordan is able to feel the grit of the country with his belly, his back and his hands; he can also smell the richness of it, hear all its voices (Malouf 2001, 122), not ghostly presences as is the case with the father, but genuine vibrating bodies and organisms all around him. To that extent, Malouf's style is emblematic of his poetic and political project, one of "imaginative possession": "Malouf has explicitly committed his writing to a project of belonging through imaginative possession" (Rooney 2019, 259). I borrow Rooney's phrase here as it sums up so aptly what Malouf is trying to do with the question of land, people and a sense of belonging. Rooney actually quotes from the second Boyer lecture Malouf gave on the perception of the land by Australians, in which he insists on a particular type of imaginative possession, not one that would serve as a pretext for physical, political and cultural appropriation of the land, but one that would inspire a form of "convergence of indigenous and non-indigenous understanding, a collective spiritual consciousness that [would] be the true form of reconciliation" (Malouf 1998, 41). Malouf tries to denounce a relationship to the land based on a mistaken understanding of what possession should be about. From a Western perspective, it is equated with individual property and exclusive rights to the land. Possessing land is thus a transitive process. From an indigenous point of view, "possessing" a piece of land means essentially being possessed by it, remaining humble, learning about the totemic ancestors who created it and transformed it, learning about the stories related to it, transmitting them from one generation to the next.

The type of gothic spectrality found in many of Malouf's writings has to do with a hauntological mode of being which opens up to the influence of the land as the recipient of a collective memory, as Rooney explains it: "The poetic architecture of his novels slows the linear chronology of plot, and readers must yield to the sensuality of 
language, the unfolding of interiorities, and the transformation of selves in the encounter with others and with place" $(2019,258)$. In "Blacksoil Country," it is precisely the complex unfolding of a settler's son's interiority and its shifting and elusive nature which calls on the reader to beware of possession in the narrow colonial sense of appropriation and choose instead to "tune the self to place through the exercise of memory and imagination as a way of cultivating belonging" (259).

Jordan merges with place in communing with it. One might argue that this is just another strategy to claim the land for the Anglo-Celtic community and their descendants in adding yet another bush tale foregrounding the sacrifice of a child and celebrating the degree of resilience, courage and endurance needed to overcome such trauma and to continue as a close-knit community. And yet, what Margery Fee designates as Romantic nationalism and the need for settler colonies to develop a "national literature" which will then "constitute[e] a land claim" $(2015,1)$ is not what is at stake here. Malouf precisely tries to go back to such founding myths and replace them with others that, far from defining a community as obtaining exclusive rights to the land in displacing another community or causing it to "vanish," gives descriptions of a white child's relation with the land as similar to the attitude Indigenous peoples have had for thousands of years: one of humility and acceptance of one's own limitations. There is also the idea that a person, in living in a place, finally becomes haunted by it, possessed by it. In the Dreamtime, typically, a child, by being born in a place, will be associated to one of the ancestral beings related to that place. Malouf is not clumsily trying to assimilate or appropriate Aboriginal culture and spirituality but he is convinced non-Indigenous people have a lot to learn from another relation to the land that would converge with that of Indigenous people.

Malouf feels that memory and imagination as well one's individual bodily interaction with the country are what should characterise a genuine, long-lasting and shared sense of belonging for Indigenous and non-Indigenous people alike. In "Blacksoil Country," it is not so much the son as the whole community who are called upon to remember. And what they should remember according to Malouf is the example given by Jordan to his younger brother Jamie: observation of both the land and the Indigenous people living in it, non-aggression, and acceptance of one's death as a necessary step in connecting with the place. Whether Indigenous or non-Indigenous, people will only establish deep connections with the land and other people who live on it if they are born on the land, feed off the land, and die on it.

And this is where the narrative tour de force lies, telling us a story of violent appropriation and possession from the perspective of a child who wishes things could have been different and will be different in the future. Malouf manages to present epiphanic moments of communion of the child with the land while at the same time pointing to the difficult choice of affiliations he is faced with, in a culture valorising a form of estrangement from the land and heroic survival in it, a culture also foregrounding appropriation, exclusion, and distinctions. As Bill Ashcroft cogently shows in his article on the child motif in both An Imaginary Life and Remembering Babylon, childhood, or more precisely infancy, the stage at which the child does not speak yet, is when possibility still prevails instead of there being a fixed place for both things and people. At this stage in his development, a human being experiences the world through his body instead of his cultural, and in this case imperial, language. His language, says Ovid about the wild child he has met while on exile from civilisation, is a 
"language whose every syllable is a gesture of reconciliation," contrary to the acquired Latin language based on "distinctions" (Malouf 1978, 94). ${ }^{4}$ But such a vision might be considered as a form of manipulation of the reader: in foregrounding the child's mystical bond with the land, Malouf might be seen as conveniently obliterating or downplaying the violence of the father's possession of it. The lack of any real interaction of the child with the Indigenous community, except as a form of mutual indifference or tolerance, might also be seen as problematic. But the most contentious issue is Jordan's quick adoption of his father's colonial stance as a matter of loyalty and filial duty.

One of the turning points in the story, from an existential viewpoint, is the passage where Jordan acknowledges a dilemma: he can either remain true to himself and refuse his father's narrow-minded stance, or accept it out of loyalty, the loyalty of filiation and descent. He is an exceptionally gifted child who has the ability to connect with just anyone, whether white settler or black Aborigine, and to that extent he seems alien to his father: "[My father] also discovered after a while, and long before I even knew what it was, that I did have it - the power, whatever it is, to soften people, win them over" (Malouf 2001, 120). Jordan is actually fully aware that his social skills might be seen as treason from his father's point of view and that he will have to prove that he remains loyal to him, "blood-loyal," whatever may happen (120). At this stage in the story such loyalty has ominous undertones. But narratively, it is a clever demonstration on the part of Malouf of the political and spiritual dead end colonial representations often lead to. Considering place and settling a place as essentially a question of filiation and blood allegiances, as a system based on distinctions between a community and its "others," is shown to only breed violence. This is all the more problematic as, if we are to take such a doctrine seriously, the settlers end up being the intruders to the new place, the invaders, the dislocated ones trying to usurp the land of another people whose blood lineage justifies a legitimate inscription in the place.

And this is where the most interesting aspect of this short story lies: its last two pages are told from the perspective of a dead teenager whose spectral voice is supposed to resolve all tensions and provide a form of conciliation and even reconciliation between non-Indigenous and Indigenous people. But we will see that such a choice of voice and poetic resolution of conflict is not without its own political and ethical ambiguities and limitations.

\section{Placelessness, Spectrality and Voice}

31 The spectrality of the narrative voice can be seen as an answer to critics who consider that Malouf has deprived Aborigines of the right to speak. Germaine Greer reproaches Malouf with denying Aborigines the opportunity to speak for themselves. The provocative points she makes foreground a complex ethical issue: how can any voice and perspective be representative or valid when it obviously represents the worldview of one community only or, at best, predominantly? Chinua Achebe in his own time asked a similar question when he reproached Joseph Conrad with having given Marlow's voice and perspective priority over those of the Congolese in Heart of Darkness.

Indeed, even before we realise Jordan is actually dead, the spectrality of the narrative voice appears in its strongly divided and shifting nature. The use of personal pronouns 
illustrates this. Jordan starts using the first-person singular before switching to the first-person plural and, in each case, he seems to be someone with a slightly different approach. At first Jordan repeats his father's words and asserts that when he and his family arrived they were the first ones on this bit of land (Malouf 2001, 116), but this is a gross misconception that his very first ramblings across the area quickly disprove. Further down, each time he is shown communing with the land, the first-person singular is used instead of the plural:

When we first come up here, $\mathrm{Pa}$ and Ma and Jamie and me, we were the first ones on

this bit of land [...]. (116)

Fact is, I loved this place we'd come to; better than any other we'd been in.

[Pa] didn't. Not really. Nor Ma neither. [...]

But I loved it. (121)

When Jordan uses the first-person plural, he tends to conflate the views of his family with those of all the settlers but this is partly contentious, as the community itself is far from homogeneous: Mick Jolley for example, one of their neighbours, is much more open-minded and fair in his approach. He feels that McGivern has the moral and social obligation to pay a compensation to make up for the death of the man he shot. Surprisingly Jordan refuses such an analysis, and starts explaining his father's point of view, as if he himself supported it: "Even when Mick Jolley came across and yelled at him and tried to get him to pay the blacks what he called compensation, I was on his side; not just by standing there beside him, but in my heart" (127). He then insists that his father never envisioned the Aborigines could have their own symbolic order and set of rules, seemingly justifying his father's violent retaliation for what appeared to him as a gesture of defiance. But in the following sentence, he also acknowledges that both his father and he himself should have known that "it was true," they did have "rules and laws hidden away in what was just makeshift savagery" (127), and the ignorance of such a fact only further proved their own estranged status in the area:

Yet it was true. There were messengers. Given a part to play like any surgeon or

magistrate, and recognized as such even by strangers.

Though not by us.

Which made us, in some ways, the most strangers of all. (127)

In such a short passage the deictic pronoun "us" points to the unplaceable point of view and voice of Jordan speaking in his name only. Mapping out the place of enunciation is impossible here. Are we to understand that Jordan speaks in the name of his community as a whole, and thus only gives the opinion of the majority of the white settlers? Or does he suggest that he was not capable himself of guessing that the Aboriginal man was coming towards the father in a conciliatory manner, as a messenger, despite his own powers of observation and his intuitive respect for the Aborigines?

How is the reader to account for the fact that the son himself is ready to side with his father, even in contradiction with his innermost intuitions and convictions? The answer is to be found in the narrative voice speaking from beyond the pale. The spectrality of the voice enables Jordan to now fully realise he was in the wrong like his father in believing he had a sort of innate right to do whatever he liked and go wherever he wanted, from place to place, without risking anything. The only reason why the Aborigines did not attack him or reproach him with being on their lands was that in their own set of rules, his presence was not a problem as long as he didn't interfere with them in a harmful way. Now that a settler has attacked one of the Aborigines, the whole settler community is to understand that their security will not be 
guaranteed any longer. But Jordan presents this as a logical consequence, no more unsettling or illegitimate than the white community's own rules:

I don't believe he [my father] knew what he had done - the full extent of it. And with all that light in his blood that made him so glowing and reckless, I don't think he would have cared.

I didn't know neither, but I felt it. A change. That change in him had changed me as well and all of us. He had removed us from protection. He had put us outside the rules, which all along, though he didn't see that way, had been their rules. (Malouf 2001, 127)

So Jordan's voice is spectral insofar as it seems to encompass two contradictory versions of young Jordan's narrated self: first his views as heavily influenced by his community and his father, and then his own intuition when he truly listens to his feelings ("I didn't know neither, but I felt it"; emphasis added). As the story unfolds, the narrating self endorses more and more the enlightened views of the young narrated self, as Jordan is now dead and he can better reinterpret the whole process of mutual distrust and aggression. The question of narrative voice and focalisation is all the more crucial as it bears on the way we should interpret the ending of the tale. There is much emphasis on the symbolism of blood, and the character-narrator suggests it is the shedding of his own blood that unites the whole settler community in their rage and desire for revenge.

This otherworldly voice also seems to imply that such an approach will only be shortlived, and that it should give way to a new sense of place, as shared by white newcomers and Aborigines alike. The disappearance and ultimate death of the child could be seen as a facile instrumentalisation of a sacrificial figure promising redemption in the communion with the land while, at the same time, refusing to fully account for the violence of the settling process in itself, by foregrounding the suffering of the settlers just as much as, if not more than that of the Indigenous people. But the first two lines of the last paragraph avoid such an easy recuperation. Pointing out that the territorialisation of Blacksoil country and Australia as a whole without any consideration of its original occupants means the loss of protection for Aborigines and white settlers alike is a way to insist that another approach is needed, based on a sense of communion and mutual acknowledgement and respect.

The blacks in every direction are hunted and go to ground. They too have lost their protection - what little they had of it. And me all that while lying quiet in the heart of the country, slowly sinking into the ancientness of it, making it mine, grain by grain blending my white grains with its many black ones. And Ma, now, at the line, with the blood beating in her throat, and his shirts, where she has just pegged them out, beginning to swell with the breeze, resting her chin on a wet sheet and raising her eyes to the land and gazing off into the brimming heart of it. (Malouf 2001,130)

The passage ends with an image of hope in which the mother finally connects with the land and finds a source of regeneration in it as if her heart was now beating in unison with it, as if the dead heart of Australia had now become a red beating heart. The ending is all the more startling as it stands in stark contrast to her first wilful indifference and denial of its presence: "She went out only to hang the wash on the line, and even then I don't believe she ever raised her eyes to the country. She just acted as if it wasn't there" (121).

Such an ending does not solve the ambiguities linked to the question of possession and appropriation. Jordan's suggestion that he is reconciled with the Aborigines in death is mostly wishful thinking. His remains, the story seems to imply, are sufficient reason for 
his family to claim ownership of the land he has been buried in, but this is a spurious argument. And yet, aesthetically, and as far as the imagination is concerned, such celebration of a peaceful integration into the landscape does have a strong affective impact on the reader. One of the main reasons for the seductiveness of such a final image is that Jordan is both loyal to his father, to the point of betraying his own beliefs and values and risking his life, and a figure of innocence in Blakean terms, at least in the first part of the story and this last image of paradoxical communion. To that extent the figure of the spectral character-narrator is very potent, as it will come to haunt the reader for its poignancy without dispelling a sense of unease and ambiguity or even complicity in the enjoyment and perpetuation of a national myth very much at odds with historical reality.

The spectrality of the narrative voice enables Malouf to conjugate two opposite worldviews in the same character-narrator: the young child communing with his country intuitively and naturally, and the faithful son trying to find his place in a symbolic order that justifies violence and the settling process as appropriation and exclusion. This is actually what Bill Ashcroft notes about the child trope in two other major Malouf pieces, An Imaginary Life and Remembering Babylon. He associates the two wild or semi-wild child figures to Lacan's imaginary order as opposed to the symbolic order, a phase of indistinction and fusion that could indicate to the readers how to revisit their sense of place that could also lead to a redefinition both of selfhood and community. If we become "the place that we have made" (Ashcroft 2001, 56), reinjecting a sense of placelessness, indistinction and reconciliation could give white settlers the possibility to be born again to this new land of theirs and to themselves.

These uncivilized children of the wilderness represent for us the psychic other of the civilized ego, the union of childhood and primitivism, the formless potentialities of a pre-Oedipal, pre-imperial language. In this sense the child's life is truly the life of Lacanian (and imperial) imaginary. In the latter novel the figure of the imaginary child breaks through into the reader's symbolic order of language and history to indicate possibilities of human adaptation to place in Australia. Gemmy is the sign of an Australia that might have been, a postcolonial imaginary. He demonstrates a potential for social change which had seemed curiously arrested at the end of An Imaginary Life. (Ashcroft 2001, 54-55)

In "Blacksoil Country" there is no child figure who occupies an in-between place as fully as the wild child in An Imaginary Life or as Gemmy, the white child rescued and brought up by Aborigines in Remembering Babylon, but there is an emphasis on the heightened perceptiveness of children. Such a foregrounding of children also entails a greater focus on the imaginary and a demonstration of their ability to truly inhabit a place in a genuinely phenomenological way, blending each of their white grains with the black grains of the country (Malouf 2001, 130). And finally the added element of spectrality, in that the child is now dead, creates a peculiar Gothic mode shedding intermittent light on the social and cultural issues at stake in the short story. One should not forget that ghosts are often "social figure[s]" and investigating them "can lead to that dense site where history and subjectivity make social life" (del Villano 2007, 5). Having a dead child as narrator, and a ghostly narrative voice wavering between various characters' perceptions of their place in the country, is a way for Malouf to haunt the readers as well, and sway them in the right direction in an affective way: "Being haunted draws us affectively, sometimes against our will and always a bit magically, into the structure of feeling of a reality we come to experience, 
not as cold knowledge, but as a transformative recognition" (Avery Gordon, quoted in del Villano 2007, 5). ${ }^{6}$

"Blacksoil Country" is a very ambivalent tale in which place and placelessness are consistently scrutinised and questioned to offer a thorough reflexion on what the settling process entails. Through the dead teenage narrator and his spectral voice, Malouf manages to reinterpret one of the canonical tropes of Australian literature, the white-vanishing trope and more particularly still, the loss of white children. He sees in the recurrence of the motif not only a deep-seated anxiety about the future of the settler colony, but also a loss of innocence in Blakean terms. The settler, the cartographer, the scientist and the explorer have all gone too far in their attempt to control, classify and analyse coldly. Malouf suggests that the child does not pass judgment. He is, however, open to the granularity of the world and makes the country his "grain by grain blending [his] white grains with its many black ones" (Malouf 2001, 130). Before the child becomes contaminated by his father's colonial ideology, he can, like Malouf himself, in his poem "A Poet Among Others," celebrate the "is-ness of things," the "blade of rye," the "moment spiralling up from the stubble field on a lark's wing," "the commonness of what is human," "grey as the dirt with its many grains, each one identical and singing":

This one was a poet, holding

to the is-ness of things: a blade of rye, a moment spiralling

up from the stubble field on a lark's wing [...]

He shares it now,

the commonness of what is human: grey, grey as the dirt

with its many grains, each one identical

and singing. The earth

in his mouth at last. Heavy as silence where the unkillable grass-seed

takes root under his tongue. (Malouf, in Williams 1998, 97-98)

\section{BIBLIOGRAPHY}

ACHEBE, Chinua. 1977. “An Image of Africa: Racism in Conrad's Heart of Darkness.” Massachussetts Review 18, no. 4 (Winter): 782-94.

ASHCROFT, Bill. 2001. "Childhood and Possibility. David Malouf's An Imaginary Life and Remembering Babylon.” On Postcolonial Futures: Transformations of Colonial Culture. London: Continuum, 54-66.

DAVIS, Colin. 2005. “Etat present: Hauntology, Spectres and Phantoms." French Studies LIX, no. 3: 373-79.

DEL VILLANO, Bianca. 2007. Ghostly Alterities: Spectrality and Contemporary Literatures in English.

Stuttgart: Ibidem-Verlag.

DUNLOP, Nicholas. 2008. “'All that Belongs to Absolute Dark': Mapping Space and Naming Place. In David Malouf's Remembering Babylon." NTU Studies in Language and Literature 20 (December): 71-96.

FEE, Margery. 2015. Literary Land Claims. The "Indian Land Question" from Pontiac's War to

Attawapiskat. Waterloo, ON: Wilfrid Laurier University Press. 
GREER, Germaine. 1993. “Malouf's Objectionable Whitewash.” The Age. 3 November.

MALOUF, David. 1978. An Imaginary Life. London: Vintage Books.

MALOUF, David. 1993. Remembering Babylon. New York: Vintage.

MALOUF, David. 1998. A Spirit of Play: The Making of Australian Consciousness. Sydney: ABC Books.

MALOUF, David. 2001. Dream Stuff. 2000. London: Vintage.

PEEREN, Esther. 2014. The Spectral Metaphor: Living Ghosts and the Agency of Invisibility. Houndmills:

Palgrave Macmillan.

PIERCE, Peter. 1999. The Country of Lost Children: An Australian Anxiety. Cambridge: Cambridge

University Press.

RATHEISER, Ulla, and Helga RAMZEY KURZ, eds. 2010. Antipodean Childhoods: Growing up in Australia and New Zealand. Newcastle: Cambridge Scholars Press.

ROONEY, Brigid. 2019. “Interior History, Tempered Selves. David Malouf, Modernism, and

Imaginative Possession." In Modernism, Postcolonialism, and Globalism: Anglophone Literature, 1950 to

the Present, edited by Michael Valdez Moses and Richard Begam, 257-76. Oxford: Oxford

University Press.

SELLES, Colette. 2009. "David Malouf's Haunted Writing." In Postcolonial Ghosts. Fantômes post-

coloniaux, edited by Judith Misrahi-Barak and Mélanie Joseph-Vilain, 269-85. Montpellier: Presses universitaires de la Méditerranée.

TABISH, Khair. 2009. The Gothic, Postcolonialism and Otherness: Ghosts from Elsewhere. Basingstoke:

Palgrave Macmillan.

TILLEY, Elspeth. 2012. White Vanishing: Rethinking Australia's Lost-in-the-bush Myth. Cross/Cultures

152. Amsterdam: Rodopi.

TURCOTTE, Gerry. 2009. Peripheral Fear: Transformations of the Gothic in Canadian and Australian Fiction. Brussels: Peter Lang.

WILLIAMS, Barbara. 1998. In Other Words: Interviews with Australian Poets. Amsterdam: Rodopi.

\section{NOTES}

1. This is how Colin Davis sums up Derrida's theory about hauntology. Davis shows how hauntology supersedes ontology - a theory the philosopher develops in his groundbreaking Spectres of Marx. Derrida's thesis was that even though Communism was by then officially dead it kept haunting Western philosophy, politics and discourse. Davis defines the spectre, or the ghost, as follows: "hauntology supplants its near-homonym ontology, replacing the priority of being and presence with the figure of the ghost as that which is neither present nor absent, neither dead nor alive" $(2005,373)$.

2. Gerry Turcotte quotes from an article by Claudio Veliz: "The Gothic Mode of Australian Culture: The 1986 Latham Memorial Lecture," in Quadrant 31 (March 1987): 8-20.

3. "If the doors of perception were cleansed, everything would appear to man as it is, infinite." (William Blake, 1998, "The Marriage of Heaven and Hell," in Selected Poetry, edited by Michael Mason, 80 [Oxford: Oxford University Press]).

4. Here Bill Ashcroft reflects on the trope of the child in Malouf's writing as an allegory of "postcolonial transformation and renewal" $(2001,59)$. He opposes the "true" language of the wild 
child in An Imaginary Life that exiled Roman poet Ovid is trying to acquire, to Latin, as illustrated in the following passage from the novel: "Latin is a language for distinctions, every ending defines and divides. The language I am speaking of now, that I am almost speaking, is a language whose every syllable is a gesture of reconciliation. We knew it once. I spoke it in my childhood. We must discover it again" (Malouf 1978, 94).

5. Achebe famously accused Conrad of being a "thoroughgoing racist" (Achebe 1977, 788).

6. For similar developments on the transformative potentialities offered by the spectrality and in-between status of a character, see Colette Selles's "Malouf's Haunted Writing." Selles sees in Remembering Babylon and Gemmy more particularly an example of "hybridity and goodwill, sympathy, fellow-feeling," all the necessary ingredients to "lay down the ghosts of history" $(2009,282)$.

\section{ABSTRACTS}

This article deals with the spectrality of the narrative voice in "Blacksoil Country," a short story from David Malouf's collection Dream Stuff (2000) in which a dead child artificially addresses the reader, as if from beyond the grave. The interrelated issues of settlement, place and placelessness are tackled through the analysis of Malouf's choice to focus on the lost child trope commonly found in Australian settler literature, and the resulting haunted nature of the disembodied narrative voice speaking from an unplaceable source. The effects of this narrative strategy include ventriloquisation, conflation and destabilisation.

\section{INDEX}

Keywords: David Malouf, narrative voice and point of view, spectrality, hauntology, lost child motif

\section{AUTHOR}

\section{CHRISTINE VANDAMME}

Université Grenoble Alpes / ILCEA4

Christine Vandamme is a senior lecturer at Grenoble Alps University. Her research focuses on space and identity, from a narratological and deconstructive perspective but also with a particular interest in the ideological, political and ethical implications of spatial representations. She has published extensively on Joseph Conrad, Malcolm Lowry, Patrick White and David Malouf. She is currently editing a volume on Space, Place and Hybridity in National Imagination in the English-speaking postcolonial world. 